\title{
Work-Life (Im)Balance? An Explorative Qualitative Study Among Mothers and Fathers of Persons with Disabilities
}

\author{
Marta Sałkowska \\ Collegium Civitas
}

DOI: http://dx.doi.org/10.18778/1733-8069.16.3.03

\section{Keywords:}

disability, parents

of persons with

disabilities, work-life

balance, meaning of work, work values

\begin{abstract}
The aim of this paper is to reconstruct the meaning of professional activity and to present strategies for coping with work-life balance among parents of persons with disabilities. Research proves that having a child with disability very often results in a lower financial status, work overload, and the necessity to manage the child's rehabilitation. The theoretical context of the study includes Herbert Blumer's concept of giving meaning to objects as well as Erving Goffman's notion of stigma by association. The context of the study is illustrated by a brief description of the sit-in protests organized by persons with disabilities and their parents in the Polish Parliament in 2014 and 2018. As such, it refers to the social policy system in Poland. The explorative study was carried out among mothers and fathers of persons with various disabilities in Poland. Individual in-depth interviews were conducted with eight participants. The results show two main types of strategy: working-mode-related and values-related. Both generational and gender differences are present in managing work-life balance.
\end{abstract}

Marta Sałkowska, PhD - assistant professor in the Institute of Sociology, Collegium Civitas. Main research interests: disability studies, qualitative research, research ethics.

\section{Contact details:}

Collegium Civitas, Pałac Kultury i Nauki

Pl. Defilad 1, 00-901 Warsaw, Poland

email address: marta.salkowska@civitas.edu.pl 


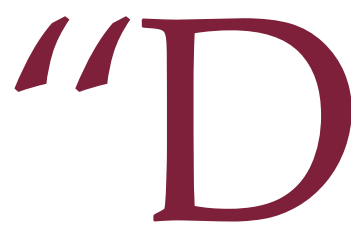

ancing backwards and in heels" - this phrase was used by one of Web portals to describe parenting a child with a disability (Think Inclusive 2014). It conveys the acrobatics that is very often performed by parents who are trying to make sure that their children are safe and provided with an education, the best possible rehabilitation, and a social life. It visualizes the attempts to achieve balance between ambitions and expectations, between social roles and various spheres of life.

The aim of this paper ${ }^{1}$ is to reconstruct the subjective meanings (see Blumer 1969) that parents of persons with disabilities give to both their family and professional roles, as well as to create a typology of work-related strategies. The main area that is investigated here is the point where work and family converge, and how they meet. This point can have only logistical aspects when the family arranges its schedule and plans, and there are no substantial connections between these two spheres of life. However, it can also be a place where these aspects interpenetrate in many different ways.

While e.g. Żaneta Stelter (2013) concentrates on the action of performing parenting roles - where the main problem addressed is if and how mothers and fathers perform social roles of parents - I am exploring different questions. How mothers and fathers maintain the balance between their family and work lives? What strategies are implemented? What are they dependent on (gender, type of disability)? How do various spheres of their life interfere with each other (if they do)? Since the social policy system in

\footnotetext{
${ }^{1}$ The article is a result of a research project funded by the Collegium Civitas internal funding scheme.
}

Poland encourages one parent (usually the mother) to give up employment and stay at home with the child, it is crucial to find out what the meanings of work are and why parents decide to work after all.

In the first part of the paper, the theoretical background and the study's context are provided. Then, the methodological issues are discussed. Later, the results are presented. Two main types of strategy are distinguished - working-mode-related and values-related. The intersections between family and work (whether and how these two spheres of a person's activity intertwine) as well as disability-related roles performed by parents are discussed. The paper closes with the conclusion.

\section{Theoretical Background and the Context of the Study}

The notion of work-life balance has become quite popular. It is quite often used in media debates in the popular press. It is mostly analyzed and discussed from the perspectives of human resources, management, public policy, and psychology (see Greenhaus and Beutell 1985; Caproni 1997; Greenhaus, Collins, and Shaw 2003; Higgins, Duxbury, and Lyons 2010). Various strategies of ensuring work-life balance are discussed and analyzed - both at public policy and institutional levels. The notion can be considered as a social-policy tool that enables people to combine their family and professional lives. The idea of work-life balance often appears when parenting is involved. Therefore, it is associated not with a private life as such, but with family or performing parental roles specifically. There are conceptions that do not concentrate on balancing the roles but, rather, on their reconciliation. Some people underline difficulties and, therefore, deal with conflicts between work and private life. Moreover, the debate and re- 
search mostly concerns obstacles faced by women as traditionally it is them who are expected to provide care (family life). As such, this issue is often raised by gender-equality movements that reveal that the question is as much personal as it is of public and political character.

There are five main types of how work and private life relate: inaction (when a person does not work, because they do not want to or are not able to), existence (when a person is forced to work and spends most of their time and resources working), hedonism (when a person does not feel the need to work, because they enjoy other activities more), integration (when a person experiences satisfaction both from personal life and work), and conflict (when a person experiences inconsistence between the private and the professional roles) (Kołodziejczyk-Olszak and Rogozińska-Pawełczyk 2008). Within the integration type, one can experience facilitation or synergy between the private and the professional roles (Rostowska 2009; Lachowska 2012; Lipińska-Grobelny 2014).

This paper tackles the issues of work-life balance from a subjective perspective, i.e. it relies on the individual's perception of whether the social roles that they identify with and perform are balanced or conflicting. It is not about public policy but, rather, about individual strategies and negotiations on the micro level. Here, I understand work-life balance as a concept referring to various social roles performed by one person and this person's perception of whether these roles are balanced or conflicting. What is this person's strategy of sustaining the balance, and is this balance really needed in the first place?

Undoubtedly, strategies are determined by the wider context. In the context of parenting a child with a disability, very often the case of mothers is analyzed. Little attention is paid to fathers and their perspective. Therefore, this study includes both angles as well as attempts to compare them. Focusing on mothers of persons with disabilities is most likely the result of the traditional patriarchal system that forces predominantly mothers to withdraw from work and perform care work at home.

Although persons with disabilities have become more visible in the public sphere (e.g. through social campaigns aimed at increasing awareness), social attitudes towards them are highly stereotyped. Disability is associated, among others, with unpredictability, aggression, anger, neglect, trustfulness, or sensitivity. Persons with disabilities are sometimes believed to be especially gifted, loving, and eternal children. These attributes are accompanied by fear, disgust, pity, shame, and helplessness (CBOS 2007). It seems that the source of these attitudes lies in the lack of knowledge and experience. People who do not have basic knowledge about - or experience with - disabilities very often feel uncomfortable when they meet a person with a disability. They do not know how to react and speak. They are confused as to how to interact both with a person with a disability and with the person's relatives.

According to Erving Goffman (1963), relatives of persons with disabilities often experience the stigma by association, or courtesy stigma. It means that stereotypes associated with disability and persons with disability (e.g. neglect and aggression, as mentioned in the results of the 2007 CBOS survey) are transferred to disabled children's parents. Therefore, there are certain social expectations from them not only as parents, but also as "special parents" of "a special child." It is very much connected to the traditional understanding of social roles. A moth- 
er is expected to totally devote herself to providing care for her child with a disability, i.e. to cancel her professional plans (Sousa 2011; Sałkowska 2015). Mothers report being blamed for giving birth to a child with a disability (Sałkowska 2015). Having such a child is sometimes perceived as punishment for the mother's past activities. They are in a situation that is judged by others - family members, neighbors, local community, other mothers who they meet in the playground. They feel stigmatized, because their children are different. The stigmatization is even stronger in that the Polish social care system forces them to give up employment.

Public opinion believes the family to be the most suitable place for children with disabilities (Ostrowska 2015). Disability in the family leads to an increase in financial needs on the one hand, and a decrease in income on the other. Employment is usually limited to one parent. It is estimated that the upbringing of a child with a disability can be up to 5-7 times more expensive than bringing up a child without a disability (Frączek 2013). Subjective and objective living conditions as well as quality of life both deteriorate (Ostrowska 2015). What is more, it leads to marginalization and exclusion from other forms of social, cultural, and public activity. Research shows that parents of children with disabilities are more likely to experience stress as they struggle with everyday care and workload. Moreover, parents in Poland can obtain certain social-care disability benefits only if one parent stops working in order to provide care. Therefore, many caregivers (mostly women) are forced to resign from work and stay at home to take care of a child with a disability. This results in marginalization as well as social, economic, and public exclusion of parents, especially mothers. Gender issues are crucial when it comes to parenting a child with a disability. Tra- ditionally, women take care of the weak in the family or community. However, this care can require them to give up employment and concentrate only on the private sphere and social roles. Even then, women also have to be advocates, physiotherapists, and speech therapists, as well as obey all orders given by the whole group of disability professionals and experts. Therefore, even though mothers act as professionals, they are doing it through the private sphere. As mothers have stated in previous research (Sałkowska 2015), it is not their duty to be an expert; their main responsibility is to be a mother. Research (Thoits 2011) shows that fulfilling many diverse social roles helps to challenge social stigma. It counteracts social, economic, and public exclusion and discrimination, and facilitates inclusion. Thus, even though the family is the best place for a child with a disability, social policy does not include the whole family. This was highlighted in the report on CRPD, prepared by the Commissioner for Human Rights in Poland; although some actions were undertaken in order to improve the economic situation of families of people with a disability, they were not aimed at enabling caregivers to work (Błaszczak 2015). Clearly, the social care system should not be aimed only at the person with a disability, but also at the individual's caregivers.

The spectacular protests by persons with disabilities, their parents and guardians that took place in Warsaw in 2014 and 2018 proved the cultural and traditional embeddedness of female socialization to perform care work and other roles in the private sphere. The protesters demanded that care work should be professionalized and treated by the authorities as regular employment (with the right to take leave and social benefits). They did not demand changing the financial support system (disability benefits), according to which only unemployed par- 
ents are entitled to receive help (see Kubicki 2017; Sałkowska 2018; Kubicki, Bakalarczyk and Mackiewicz-Ziccardi 2019). They were living with their children, many of whom were already adults. Obviously, this situation raised moral issues related to the exploitation of a disability in order to receive higher social benefits (Linczerska 2016). However, it was also an act of desperation and helplessness. Crossing the boundaries between private and public spheres seemed the only way to attract public (and politicians') attention. That protest forced a question to be asked about whether care issues are private or public. For sure, care is political as well as gender-related. Apart from moral aspects, the protest raised issues of social expectations and the social role of a disabled child's parent. The main postulate raised by the protesters was about obtaining higher social benefits (related to disability), not about rebuilding the social-policy strategy. It was not the question of whether a caregiver could work and receive social benefits; rather, the benefit's amount was discussed. As a result, as far as caregivers and employment is concerned, the protest has only strengthened the status quo. It also showed that most of the traditional social roles and expectations are fulfilled by the parents. In the media, social policy analysis was rare (Sałkowska 2018).

The briefly described context reveals that occupying professional roles and parenting roles for a person with a disability can be difficult and can cause a feeling of imbalance rather than balance as this combination is not supported and welcomed by the social-policy system. However, this context makes the issues of work-life balance among parents of persons with disabilities even more intriguing, and especially so when the fathers' perspective is to be analyzed, since "disability has a feminine face" (Laksa 2017).

\section{Methodological Assumptions}

The explorative study was carried out with eight participants (five women, three men). Purposive sampling was applied. Each participant had to meet the following criteria: to be a parent of a person with a disability (child, teenager, adult)and to have a job/ employment. Individual in-depth interviews were carried out, recorded, and transcribed. The interviews were based on an elastic guide and very much depended on the particular interviewee. However, among the main issues tackled in each interview there were: family situation, disability characteristics, networks of support (both formal and infor$\mathrm{mal}$ ), and social roles performed by the interviewee.

The interviews were recorded verbatim and anonymized transcriptions were made. The qualitative interviews' analysis was carried out with the support of the Atlas.ti software. A combination of theoretical and open-coding approach was implemented. Primary theoretical codes were completed with codes that emerged through multiple readings of the transcripts (Gibbs 2007). The interviews were interpreted using Blumer's idea of a meaning as well as symbolic interactionism. According to Blumer, human beings act toward social objects and other beings in their surroundings according to meanings that these objects have for them. These meanings arise from social interactions and are established and modified through an interpretive process (Blumer 1969; Schwandt 1998). It is important that social interaction is understood broadly, i.e. as communication between and among individuals. During the analysis, main topics associated with work and family roles were sought in order to reconstruct the meanings of professional career and private/family life. It is important to notice that meanings are determined not only by social com- 
munication, but also by the individual's previous experiences with disability, work, family, and the wider socio-cultural and economic contexts. In the course of the research, the context was mainly built by the protests in the Parliament and the (lack of) support system that acknowledges the needs of families and persons with disabilities. The analysis also sought parents' actions that relate to social reactions; the aim was to find out if and how they experience stigma by association.

As the inquiry dealt with a vulnerable social group (see Liamputtong 2007), special attention was paid to ethical issues - the research was conducted in accordance with the Code of Ethics of the Polish Sociological Association. Each participant was asked for informed consent and could withdraw from the study at each stage. The interviewees were self-recruited after having been reached via various communication channels, including formal and informal contacts, and employees of non-governmental organizations. Some interviews were carried out via telephone due to logistic difficulties. The interviews were carried out between January and March 2019.

Each participant was a parent of a person with a disability. Among the types of disability there were sensory, intellectual, and multiple disabilities. One person had a child with an acquired disability.

\section{Analysis}

\section{Working mode-related strategies}

Some parents - especially those of pre-school and school children with conjugate disabilities - try to adapt their working mode so that it can meet the needs of their children's rehabilitation. They high- light the difficulties that regular full-time working mode ('from 9 to 5 ') creates when it comes to other activities that are necessary when one has a child with a disability. Parents of children with disabilities have to make more appointments with various professionals and specialists, e.g. speech therapists, physiotherapists, psychologists. The appointments' schedules influence family life and sometimes make it impossible for both parents to work full-time. Some parents report that flexible working hours are a consequence of their profession (academic, researcher, freelancer) or the type of work they perform (owner of a small enterprise, therapist). Other parents say the flexibility is a consequence of decisions made after a child with a disability had been born.

The father of a five-year-old boy with multiple disabilities said:

He has rehabilitation at 13.00. And now the situation is such that you have to finish work so that at 12.30 you take him from school to this rehabilitation. There is one hour of sitting there and waiting to pick him up. That means you do not earn. You do nothing (...) He has rehabilitation at 9.00 in the morning, so you drive him at 9.00 , pick him up at 10.00 , drive him to school and go ... it is really enough to lose a normal, regular job, isn't it? (...) for example, our school is open until 15.30. I have to finish my work at 14.30 (...) and when, because I'm the chairman of the parents' council and I wanted to do something about it, but it turned out that we are the only parents who work and apart from us no parent sees the trouble (...) Because if you don't work, you don't see that it can be difficult. Because you just leave, take away, no problem. [P3 $]^{2}$

\footnotetext{
${ }^{2}$ All quotes from the interviews were translated by the author.
} 
This citation is an exemplification of a broader problem, namely the education system is organized and planned in a way that does not meet the requirements of a regular labor market. In a dual-earning family with a disabled child it seems impossible for both parents to have rigid working hours, especially when the child needs special support, rehabilitation, and more doctors' appointments. Multiple disability rehabilitation requires participation in rehabilitation stays:

Each stay costs 5,000 PLN and we have to be there every 2 or 3 months. [P3]

The mother of a nine-year-old boy with an acquired disability has said that she has not returned to work as a full-time employee. Her flexible working mode has been a consequence of her child's disability and the necessity to organize and manage his rehabilitation:

Everything was adjusted to the rehabilitation scheme, doctors' appointments. It all happens during the day. You can't have speech therapy at 18.00 or 19.00. [P6]

The need to adjust the working mode of one or both parents is more noticeable among parents of children with multiple disabilities as well as when children are small. In such cases, the disability requires more frequent, regular, and intensive rehabilitation. This rehabilitation very often involves the parents to perform it (some parents, apart from being parents, are also professional-amateurs when it comes to rehabilitation and their children's therapy - this case will be discussed later).

In some cases, the working mode is secondary to the disability (a consequence), whilein other cases it is primary. Even though flexible working hours defi- nitely make professional activity possible while parenting a child with a disability, work itself may be a source of frustration and feelings of uncertainty. This is very strongly reported by a mother of twin boys who are on the autism spectrum. She is an academic and a scientist, and cannot fulfill all her professional obligations, e.g. participation in conferences or study visits:

Elements of my professional development path seem impossible for me to perform. And I wonder what my future will be like if I fail to perform. [P1]

Like That father [P3] above, this mother [P1] also underlines the difficulties of working from home. Even when a person has a dedicated working space at home, it is difficult to draw a line between one's family and professional lives, which causes clashes between the two. The mother [P1] said:

The huge conflict is that this is a job [academic] that requires concentration and apart from some days when I can get to it in the morning, then in the afternoons it is very difficult (...) Because there are different conditions, yes, for work, I have quite poor conditions for working at home, but that's the situation, right? For now, we are not able to change the apartment. So, we work in such a fairly small room together and as I hear children all the time somewhere, they are still coming and going, somewhere they pull me out of this focus. So, I have a big problem with reconciling it in that sense, yes, such quiet time, the concentration needed for research work, well, that's a problem. [P1]

It is noticeable that flexible working hours do not solve the problem of performing one's job while having a child with disabilities. The type of work also has to be taken into account. Obviously, having children and working is not an easy task, but it 
becomes even more difficult when accompanied by the child's disability.

Some parents report the advantages of permanent employment. A father of an adult woman with cerebral palsy [P4] said he and his wife had always been working full-time and had always had permanent working hours that allowed them to plan doctors' appointments and rehabilitation. Now the man is still working and his wife is retired. When both of them were professionally active, they employed a sitter, and their daughter spent some time at a boarding school. According to him, a permanent job has many advantages, such as social security or paid leave. A self-employed father [P3] also emphasizes these issues, but considers it impossible to fulfill obligations and be reliable at the same time:

Permanent jobs are interesting, (...) you get L4 [sick leave - MS] and holidays, but there is also an obligation and I will not be able to do something, because I will have to be somewhere else in my working hours. And now I am able to cancel, reschedule, or catch up. [P3]

These variances in the perception of a permanent job may be a consequence of generational differences. The father of the adult woman is now at the end of his professional career, but the majority of the care work was his wife's duty and responsibility. Still, he admits that his wife has a leading role in their relationship. She is a sort of manager and he fulfills the tasks. He used to be the driver when his wife made an appointment with a specialist. He spends time with his daughter and they have fun hiking or going to the swimming pool. However, it is his wife who does the care work. Today, on the other hand, fathers of children with disabilities are becoming more involved in the care work. Both mothers and fathers admit that this part of being a parent is im- portant to men. Also, women are more willing to let their partners do the job. The mother of a boy with an acquired disability makes a joke:

His father is also like a mother (...). We split fifty-fifty. We have a partnership model. So, all the successes and failures we split into two. And the same with the responsibility and care. [P6]

However, these differences may also be a result of a general trend, according to which fathers as role models and the meanings of fatherhood have recently been changing. This also concerns families with a disabled child. Moreover, the rehabilitation offer is much richer now than it used to be twenty years ago, as well as information is easier to access. Parents see more opportunities for their children. It is also probable that the expectations and social pressure to rehabilitate children are higher.

Apart from gender-related issues that influence the perception of working modes, there are some cases that suggest that the type of disability also matters, which is nothing new when research among persons with disabilities is concerned. There are some types of disability that professionals and the society are familiar with, e.g. visual disability. The Polish Association of the Blind was established in 1951, but some supportive actions (mostly of charity) for persons with a visual disability have been undertaken since the $19^{\text {th }}$ century. There are pre-schools, schools, and boarding schools for children with a sight impairment. What is interesting is that very often children with multiple disabilities or with cerebral palsy are also admitted to learn there. The mother [P5] of two girls (ten and seven years old) with a visual disability has a permanent job, working full-time. Her daughters attend an integration class in a regular school. Although the woman is working full- 
time, she does not report difficulties in organizing rehabilitation or therapy for her children. As has been said, this may be due to the fact that visual disability is relatively well-known and the requirements are clear for both professionals and parents.

Parents' working mode may be primary or secondary to their child's disability. Some of them practise professions that are based on flexible working hours. There are parents who value permanent full-time work. Others prefer being a freelancer and having more flexibility in order to manage everyday family logistics.

\section{Meanings of work: Value-related strategies}

Having a child with a disability and working at the same time is like balancing on a rope and it is not supported and promoted by the social policy system. This issue is often raised by the interviewees. One mother [P6] does not understand the logic of the social policy system. She claims it is more profitable for both the family and the state if parents (mother and father) work, earn, and pay taxes:

It is better for me to simply go back to the labor market and pay these taxes than to take this allowance. Well, just a sick system. Sick, not to earn some money or some extra money when this child is in school or kindergarten, or to do anything. This is total exclusion from the labor market and the regulations lead us to stay at home. I didn't take it [the allowance MS], I didn't quit my job. [P6]

The mother of a twelve-year-old boy with cerebral palsy adds:

This is not well-perceived [that I work - MS]. I would like someone to tell me: “Nice, so you actually do something for the benefit of others, good for you and even for the state." And they don't pay my social security. [P2]

Another issue is how the parents' professional activity is perceived by local officials (e.g. social workers) and other parents of persons with disabilities. The father of a five-year-old boy [P3] notices that his economic status has been underlined by the PFRON employees when he applied for the co-funding for his son's rehabilitation stay, which he is fully entitled to as it does not depend on the family's income. The official suggested that maybe he should not apply for it. Each year the interviewee and his wife carry out a private campaign aimed at collecting funds within the $1 \%$ scheme. $^{3}$ This funding allows their son to participate in rehabilitation stays more often. The research participant explains that when his family is planning a holiday, he tends to wonder what other people might think if they decide to go on a more expensive trip or somewhere abroad: would they still give their $1 \%$ to his son? Maybe they would think that if he can afford such an expensive holiday, then maybe he does not need this kind of support? Such dilemmas are quite reasonable when one remembers the discussion initiated by a photograph from a holiday in Croatia which was posted on a Facebook profile by one of the protesters. It has revealed that parents of persons with disabilities are expected to sacrifice for their children rather than to live a 'normal life.' The mother should, as one of the interviewees said, "cover herself with a bag" instead of wearing nice clothes, make-up, and generally take care of herself. A similar situation arose when one participant of a protest was wearing an expensive

\footnotetext{
${ }^{3}$ Each year tax payers in Poland can donate $1 \%$ of their annual tax to a chosen organization (there are also individual accounts within organizations).
} 
scarf. This issue was also raised in the Theater $21^{4}$ performance titled "Revolution That Wasn't," which presents, among other things, the social expectations towards mothers of persons with disabilities.

If the whole matter is so complicated and not supported by the social policy, why do both parents decide to work? What are the advantages that they experience? What meanings do they give to their professional activity? With what values do parents associate work and professional activity?

When it comes to the benefits of work experienced by the interviewees, finances are the first aspect, which is mentioned mostly by men:

Currently, after so many years of work, I can honestly say that [work gives me - MS] money. [P4]

The author of this quote is at the end of his professional career and admits that now he is only waiting for the retirement and does not seek development at work. He perceives his financial situation as very good, but claims that it was more complicated when he was younger as he had to prove himself to be worthy of his position and salary:

Work had a different meaning, because I had to prove myself in this job, well, generally, because it was necessary for me to support my family. [P4]

As was shown in the first part of the paper, having a child with a disability translates into higher

\footnotetext{
${ }^{4}$ Theater 21 (Teatr 21) is the first professional theater company in Poland where the majority of actors have Down syndrome. More information about their activities, in English, can be found at http://www.polishtheatrejournal.com/index.php/ptj/ article/view/85/348. "Revolution That Wasn't" is based on real events that occurred during the 2018 protest by persons with disabilities and their parents and guardians in the Polish Parliament.
}

expenses. This concerns especially children with an intellectual disability, multiple disabilities, or cerebral palsy. Parents have to pay for rehabilitation, doctors' appointments, special equipment, and - sometimes - rehabilitation stays. One father [P3] said:

Our task is to earn enough money to pay someone who can do it [the rehabilitation - MS]. I mean, I do what I can to pay someone to do something that they can do. [P3]

Being able to provide specialist rehabilitation, speech therapy, and other services recommended by professionals means that a parent performs the role of a parent, not of the many other specialists that are required (this issue will be discussed later).

Having a child with a disability very often translates into the need to ensure the child's future so that they can be as independent as possible in their adult life. As a child grows up, parents are more often confronted with thoughts and fear about the future - mostly their child's future after their death. The father of an adult son with multiple disabilities [P7] said:

At the end we have [to make sure - MS] that he has something safe. [P7]

The mother of twins on the autism spectrum said that even though sometimes she wanted to give up her work, she still feels she should work:

I simply have to work to earn, so for sure, even if such a thought appeared, especially when these things are all building up, tremendous fatigue, I had thoughts that maybe I should give up and take these allowances. [P1] 
She adds:

We are aware that we should start putting away some money for their [sons' - MS] future needs somehow, but if I quit my job, we certainly would not be able to save anything at all (...) thinking that we will not be able to leave them anything like this? So, even if such thoughts appeared, they were pushed away very quickly, sometimes these thoughts were that I am afraid that I will lose my job, right? [P1]

Working also means having your own money. One woman [P2] underlines that it makes her feel safe. Her husband is not the only breadwinner in the family. If something happens to him, the family will survive. Otherwise, the allowance would not be enough.

Apart from financial benefits, parents also experience other gains from their professional activity. One of the most important is the feeling of satisfaction. Parents report it quite often. The mother of twins on the autism spectrum admits that although she "does not work for the work itself," satisfaction and the feeling of fulfillment are also important:

Thinking that I can do something, because in some areas of our work we work better, in others a little worse, (...) it gives me satisfaction that, well, I'm doing something that theoretically belongs to some prestigious profession, right? Because a researcher, an academic should basically be treated this way. This is not always the case, because when you look at your account, this prestige decreases, but I'm satisfied with the pace, I also count on some praise, or if I manage to succeed, well, but this material aspect is very important, I do not hide that. [P1]
The job [gives me - MS] satisfaction, contact with others, that I am still important, that I am able to share knowledge, some energy, a lot of young people in general, and the fact that I can simply share my knowledge. [P6]

The mother of a twelve-year-old boy with cerebral palsy admits that when she stayed at home (for ten years) she sometimes felt ashamed when someone asked where she worked:

Mentally, of course, I had a great excuse [for not working - MS], but I missed it somewhere under the skin and that's why I felt I was genuinely ashamed of it, and somewhere there I felt that I still didn't use any potential. [P2]

After she returned to work, "the life has begun again" [P2]. Her professional activity is the source of feelings and emotions that she does not experience at home. Of course, she is excited when the rehabilitation of her son brings results, but the satisfaction and pride resulting from work are of a different quality:

[It is - MS] different, quite different, I mean when [my son - MS] started taking his first steps, for example, he started walking a bit, it was a great joy, but it was quite different, that is, I will not say that one is better or the other, only different. Yes, that this fulfillment, professional, I needed it, it was deep inside me. [P2]

And even though the woman gets up at 4:30 a.m. every day, she would not like to give up her work. She likes her team and feels appreciated both by her co-workers and her superiors. At home she does not feel that way as her husband supports her but appreciates only those achievements which are somehow work-related: 
I always hear that I am a key employee, even if I have an idea to do something somewhere else, to go to a different department, I hear "No, no, no, you have to be with us because you are the whole department, it won't work." I am proud. At home I sometimes hear that I am the worst mother in the world! My husband doesn't tell me such [nice - MS] things, although not when I finished my studies or when I went to work, then he told me that he was proud of me, but maybe I was not entirely proud of the housework. [P2]

A lack of pride in the housework may be associated with the general image of a housewife that this particular woman had:

I have a picture of such a stupid woman sitting at home (...) with limited intellectual potential. [P2]

Women usually "love their work" and do not imagine themselves as housewives [P5]. Apart from generating satisfaction, professional development and fulfillment at work also enables contact with other people. This social aspect of work relations seems quite important. Women say that they like meeting people, talking to them, helping them. They like all these interactions that are related to work. Moreover, going to work very often means leaving the disability enclave that seems to be the 'natural environment' of women with disabled children. At work, women are perceived not as mothers of a child with a disability, but as a competent employee whose primary task is to perform her professional duties:

I was with him all the time in such a world of disability and it was the case that my friends had disabled children, and it was all about it, and when I am at work I am in a different world, I have to finish the project, I have to, and my thoughts are not at all "What is he doing?" or "Will he be able to do it or not?". I mean, it happens later at home or in other situations, but I have to focus on quite different things. [P2]

Work may also have therapeutic effects. It serves as a kind of distraction from everyday routine. As one mother puts it:

But after, after two years, just when I was sleepy, then I began to forget that I wasn't somewhere for some rehabilitation, that I missed something, I started to malfunction, so... I felt it and it was recommended by therapists that I should also have my distraction, that I have this window to do something else, just work, where I feel fulfilled. And that's how it allowed me to function (...) a distraction, I started to function better then. [P6]

On the one hand, work can be a stepping stone, and on the other - as the mother of a sixteen-year-old girl with an intellectual disability [P8] claims - an escape. She returned to work when her daughter was six years old and she felt absorbed with her professional activity:

I really felt that I can catch my breath at work, I somehow rested [at work - MS]. Now if I have to choose: run a weekend workshop or stay at home, I take the needs of my girls more into account. And it is them first, and then work. [P8]

The woman noticed that being preoccupied with work had been a way to run away from the situation at home. Now she is trying to be more conscious while taking professional decisions and she tries to analyze their advantages and disadvantages in the context of her daughters.

Professional activity enables women to perform different roles, not only the role of an employee: 
I think I have such a guiding role in general. That I show the girls [co-workers - MS] different things, and that it is possible that if they say "no," the world will not collapse, and that, I don't know, that you can be happy outside of marriage, because they have various ones, (...) it may sound so ridiculous, but when I come they say "Oh, our queen is coming" and that's it. [P2]

As far as values and benefits are concerned, work provides money and financial issues are the most obvious and natural advantage of employment. Earnings translate into safety that is especially valued by the parents of persons with disabilities. First of all, it is essential when it comes to meeting the needs resulting from disability. Secondly, financial security and savings are crucial for securing their child's future. Other gains from professional activity are connected to self-esteem, the need for appreciation, and satisfaction. Moreover, especially when it comes to women, working means having interactions with people who are from outside the disability enclave. Results prove that the conception that performing various social roles in different spheres of life helps to cope with stigma and prevents discrimination and exclusion (Thoits 2011).

\section{Intersections of work and private lives}

Work helps parents not to feel overwhelmed by the daily routine in various ways. One father [P3] draws energy from his job and uses it at home, while playing with his three children. Quotes from the women mentioned above indicate that work provides different kinds of experiences and interactions. The interviewees underline that at work they are perceived as someone else, i.e. being a mother of a child with a disability is not their central role. Perhaps they are trying to set a clear divide between their professional and family activities, even when the scale and the mode of their professional involvement may be limited or determined by the child's disability.

On the other hand, one man reports that his personal and professional activities interpenetrate. His private life can be an inspiration for work, and the other way round. One father [P3] describes it in the following way:

What I do strongly corresponds with home relationships. This means that the more I know about upbringing in terms of training, the better I will also bring up my children and vice versa. That with each board game I will get to know it better at home, then I will sell it better, for example on a talk about values and with each workshop, when I have to prepare myself in some area, for example, the emotional development of an eleven-year-old child reminds me at what stage my son is and when I return too, I come back refreshed, right?

I think I like the moment the most, the point when, when family life intertwines with work and workshop, you know? [P3]

This attitude of allowing the private life into the public, professional life is coherent with fathers' experiences presented in the book titled Lista Obecności (Attendance List) (2017), which contains a collection of interviews with fathers (public persons) of persons with disabilities. It shows that private experiences related to parenting a person with a disability very often intertwine with public activity, be it professional life (e.g. dealing with art) or some kind of social activity. In other words, work can be a sphere where they, in a positive sense, make use of their children's disability. Both spheres facilitate each other, i.e. being a good employee enables one to be a better parent, while at the same time parenthood increases the quality of professional work. 


\section{A parent or a parent-professional?}

A social campaign was run in Poland some time ago. In the streets there were billboards that presented a man or a woman and a child with a visible disability. They featured slogans: "I am a mother. Not a rehabilitant." or "I am a father. Not a therapist." This campaign illustrates social and professionals' expectations towards the parents of disabled children. The parents are expected to fulfill all the recommendations issued by the various specialists they have appointments with. In some cases, they (mostly mothers) become speech therapists, physiotherapists, pedagogues, psychologists, teachers. With so many duties, it is extremely difficult to be a parent. Some of my interviewees needed to learn more about disability after their child had been born and diagnosed. One father [P3] enrolled in university and studied special education. Feeling obliged and trying to become a parent-professional may result in frustration and burnout.

Elderly male research participants appreciate all the work that their wives did when their children were small and required intensive rehabilitation. They remember hours of exercising, difficulties, and tears.

Younger interviewees underline that working enables them to hire specialists and gain time to fulfill parental roles, especially when - apart from a child with disabilities - they have other children who also need their parents. One father [P3] claims that it is better to pay someone who knows their job than for him to learn how to do it. He also notices that rehabilitation and therapy have better outcomes when they are carried out by someone else, not the parents. For some interviewees, this process of admitting that someone else is also capable of taking care of their child took a long time. It took two years for one mother [P6] to understand and accept that trying to do everything by herself results in extreme fatigue and burnout.

\section{Conclusion}

Work-life balance does not mean that work and family are equally important elements. It means that if one sphere is more important to a particular person, they should organize the other sphere in a way that does not interfere with the first one. Although work is important for the interviewees, it is especially women who underline that they would give it up if their children's condition required it. Some of them have said that going to work every day is something they liked most in their lives, but their families still remained crucial. They decide to work only if they are convinced that their children are safe and properly taken care of. It also has a psychological aspect - one mother had spent about ten years at home until she was sure she had done everything for her son that was possible, and became ready to return to her professional activity. Another woman said:

Yes, and my child got a therapist - an assistant in kindergarten - and I won integration education so that I could see that the more this environment behind me can take care of him too, I don't have to be with him seven days a week, twenty-four hours, all the time with him and the guardian angel. Only that he should already have friends, he learns, I can see, from children, in his natural environment he can learn more from healthy children than being at my home with all the individual therapies. [P6]

Parents perceive their professional activity not only in the private context of their household economy or personal ambitions, but also in a wider context, e.g. as tax payers. What is more, their professional life contradicts the social expectations of what it means to be 
a parent or a care provider to a child with a disability. They are professional, successful, and satisfied with their lives. They resist the social reaction that Goffman calls stigma by association (Goffman 1963).

The parents' working mode is usually determined by their children's schedules: nursery, preschool, school, appointments with specialists, therapy, rehabilitation.

In the case of my interviewees, it may seem more significant to find a balance between their own view of life and the views that other people and institutions have

\section{References}

Blumer, Herbert. 1969. Symbolic Interactionism: Perspective and Method. Englewood Cliffs: Prentice-Hall.

Błaszczak, Anna, (ed.). 2015. Realizacja przez Polskę zobowiazań wynikajacych z Konwencji o prawach osób niepetnosprawnych. Sprawozdanie Rzecznika Praw Obywatelskich. Warsaw: Biuro Rzecznika Praw Obywatelskich.

Caproni, Paula J. 1997. “Work/Life Balance. You Can't Get There From Here." Journal of Applied Behavioral Science 33(1):46-56.

CBOS. 2007. Komunikat z badań „Postawy wobec osób niepełnosprawnych".

Frączek, Piotr. 2013. "Rodziny wychowujące dzieci z niepełnosprawnością i ich oczekiwania wobec polityki społecznej."Wrocławskie Studia Politologiczne 15:46-63.

Gibbs, Graham. 2007. Analyzing Qualitative Data. London: SAGE Publications.

Goffman, Erving. 1963. Stigma. Notes On the Management of Spoiled Identity. New York, London, Toronto: Simon \& Schuster.

Greenhaus, Jeffrey H. and Nicholas J. Beutell. 1985. "Sources of Conflict Between Work and Family Roles." The Academy of Management Review 10(1):76-88. designed and planned for them as parents of disabled children. Sometimes, it is not a question of whether to work (because for some of them it is natural), but, rather, how to organize it. Everyday logistics reported by the interviewees shows the lack of a system of support that would meet the actual needs of parents that want to or have to work. It contradicts the main demands of the protesters in 2014 and 2018, which focused on the increase of social benefits instead of supporting care providers that decide to be professionally active. Results also show that most of these parents experience the integration between family and work life.

Greenhaus, Jeffrey H., Karen M. Collins, and Jason B. Shaw. 2003. "The Relation Between Work-Family Balance and Quality of Life." Journal of Vocational Behavior 63:510-531.

Guest Blogger. 2014. "Dancing Backwards and in Heels: Parenting a Special Needs Child." Think Inclusive (March 28). Retrieved March 21, 2020 (https://www.thinkinclusive.us/dancing-backwards-and-in-heels-parenting-a-special-needs-child/).

Higgins, Chris A., Linda E. Duxbury, and Sean T. Lyons. 2010. "Coping with Overload and Stress: Men and Women in Dual-Earner Families." Journal of Marriage and Family 72(4):847-859.

Kołodziejczyk-Olszak, Izabela and Anna Rogozińska-Pawełczyk. 2008. “Miejsce oceny i wynagradzania efektów pracy jako obszar programów praca-życie." Pp. 161-171 in Równowaga. Praca-Życie-Rodzina, edited by C. Sadowska-Snarska. Białystok: Wydawnictwo Wyższej Szkoły Ekonomicznej w Białymstoku.

Kubicki, Paweł. 2017. Polityka publiczna wobec osób z niepełnosprawnościami. Warsaw: Oficyna Wydawnicza SGH.

Kubicki, Paweł, Rafał Bakalarczyk, and Marek Mackiewicz-Ziccardi. 2019. "Protests of People with Disabilities as Examples of Fledgling Disability Activism in Poland." Canadian Journal of Disability Studies 8(5). Retrieved March 21, 2020 (https://cjds. uwaterloo.ca/index.php/cjds/article/view/569). 
Lachowska, Bogusława. 2012. Praca i rodzina - konflikt czy synergia? Lublin: Wydawnictwo KUL.

Laksa, Kobas. 2017. “Nie czuję, żebym się różnił od matki." Pp. 94-113 in Lista Obecności 2017. Rozmowy z ojcami niepetnosprawnych dzieci, edited by E. Zakrzewska-Manterys and A. Suchcicki. Warsaw: Bardziej Kochani.

Liamputtong, Pranee. 2007. Researching the Vulnerable: A Guide to Sensitive Research Methods. London: Sage Publications.

Licznerska, Agnieszka Lena. 2016. "Disability and Ethics: A Parent Action in Poland." Forum Oświatowe 28(2):49-64. Retrieved January 28, 2018 (http://forumoswiatowe.pl/index.php/ czasopismo/article/view/463).

Lipińska-Grobelny, Agnieszka. 2014. “Wielość ról a równowaga między życiem osobistym i zawodowym." Pp. 14-27 in Rodzina i kariera. Równoważenie czy konflikt ról?, edited by I. Janicka and M. Znajmiecka-Sikora. Lodz: Wydawnictwo Uniwersytetu Łódzkiego.

Ostrowska, Antonina. 2015. Niepełnosprawni w społeczeństwie 19932013. Warsaw: Wydawnictwo Instytutu Filozofii i Socjologii PAN.

Rostowska, Teresa. 2009. Małżeństwo, rodzina, praca a jakość życia. Cracow: Oficyna Wydawnicza Impuls.
Sałkowska, Marta. 2015. Matka Downa. Piętno. Znaczenia. Strategie. Cracow: Zakład Wydawniczy NOMOS.

Sałkowska, Marta. 2018. “Sejmowe protesty opiekunów osób z niepełnosprawnościami - wybrane wątki analityczne artykułów prasowych." Societas/Communitas 2-2(26-2):233-246.

Schwandt, Thomas A. 1998. "Constructivist, Interpretivist Approaches to Human Inquiry." Pp. 221-259 in The Landscape of Qualitative Research: Theories and Issues, edited by N. K. Denzin and Y. S. Lincoln. Thousand Oaks, London, New Delhi: SAGE Publications.

Sousa, Amy C. 2011. "From Refrigerator Mothers to Warrior-Heroes: The Cultural Identity Transformation of Mothers Raising Children with Intellectual Disabilities." Symbolic Interaction 32(2):220-243.

Stelter, Żaneta. 2013. Petnienie ról rodzicielskich wobec dziecka niepetnosprawnego intelektualnie. Warsaw: Difin.

Thoits, Peggy A. 2011. "Resisting the Stigma of Mental Illness." Social Psychology Quarterly 74(1):6-28.

Zakrzewska-Manterys, Elżbieta and Andrzej Suchcicki, (eds). 2017. Lista Obecności 2017. Rozmowy z ojcami niepetnosprawnych dzieci. Warszawa: Bardziej Kochani.

\title{
Citation
}

Sałkowska, Marta. 2020. “Work-Life (Im)Balance? An Explorative Qualitative Study Among Mothers and Fathers of Persons with Disabilities." Przegląd Socjologii Jakościowej 16(3):40-55. Retrieved Month, Year (www.przegladsocjologiijakosciowej.org). DOI: http://dx.doi.org/10.18778/1733-8069.16.3.03

\section{Work-Life (Im)Balance? Jakościowe badanie eksploracyjne wśród matek i ojców osób $\mathrm{z}$ niepełnosprawnościami}

\begin{abstract}
Abstrakt: Celem artykułu jest rekonstrukcja znaczenia pracy zawodowej oraz strategii radzenia sobie z tak zwanym work-life balance wśród rodziców osób z niepełnosprawnościami. Bycie rodzicem dziecka z niepełnosprawnością bardzo często oznacza niższy status ekonomiczny, obciążenie pracą oraz konieczność zorganizowania rehabilitacji. Teoretyczny kontekst badania stanowi koncepcja nadawania znaczeń obiektom (Blumer) oraz pojęcie przeniesionego piętna (Goffman). Ponadto społeczny kontekst wyznacza krótki opis protestów rodziców i opiekunów osób z niepełnosprawnościami w parlamencie (2014 i 2018) oraz zarys systemu wsparcia. Jakościowe badanie prowadzone było z matkami i ojcami osób z różnymi niepełnosprawnościami. Przeprowadzono osiem indywidualnych wywiadów pogłębionych. Na podstawie zebranych danych wyróżniono dwa główne typy strategii: zorientowaną na tryb pracy zawodowej oraz zorientowaną na wartości związane z pracą. Zaobserwowano również różnice w strategiach uwarunkowane genderowo oraz pokoleniowo.
\end{abstract}

Słowa kluczowe: niepełnosprawność, rodzice osób z niepełnosprawnością, work-life balance, znaczenie pracy, wartości pracy 